Abstracta Iranica Abstracta Iranica

Revue bibliographique pour le domaine irano-aryen

Volume 40-41 | 2019

Comptes rendus des publications de 2017-2018

\title{
Sandra Aube. La céramique dans l'architecture en Iran au XVe siècle. Les arts qarâ quyûnlûs et âq quyûnlûs
}

\section{Iván Szántó}

\section{(2) OpenEdition}

\section{Electronic version}

URL: http://journals.openedition.org/abstractairanica/47908

DOI: $10.4000 /$ abstractairanica.47908

ISBN: 1961-960X

ISSN: 1961-960X

Publisher:

CNRS (UMR 7528 Mondes iraniens et indiens), Éditions de l'IFRI

Electronic reference

Iván Szántó, "Sandra Aube. La céramique dans l'architecture en Iran au XVe siècle. Les arts qarâ quyûnlûs et âq quyûnlûs", Abstracta Iranica [Online], Volume 40-41 | 2019, document 2, Online since 15 July 2019, connection on 24 April 2021. URL: http://journals.openedition.org/abstractairanica/47908 ; DOI: https://doi.org/10.4000/abstractairanica.47908

This text was automatically generated on 24 April 2021.

Tous droits réservés 


\title{
Sandra Aube. La céramique dans l'architecture en Iran au XVe siècle. Les arts qarâ quyûnlûs et âq quyûnlûs
}

\author{
Iván Szántó
}

\section{REFERENCES}

Sandra Aube. La céramique dans l'architecture en Iran au XVe siècle. Les arts qarâ quyûnlûs et âq quyûnlûs. Paris/Téhéran : Presses de l'Université Paris-Sorbonne / IFRI, 2017, 284 p., 287 figs., multiple ill., ISBN: 979-10-231-0525-4

1 This monograph about architectural decoration in 15th-century Iran (and beyond) is the first of its kind not only because of its subject matter but also with respect to its emphasis on the Turkmen dynasties. Until the recent increase of studies on Turkmen cultural patronage, the Āq Quyūnlū and Qarā Quyūnlū seemed to be perpetually overshadowed by their Timurid rivals in scholarly literature. Sandra Aube's monograph, along with those by Simon Rettig and Chad Lingwood, seeks to counter this imbalance.

2 Although the ornamental potential of vaulting and stucco was as skilfully exploited by Persian craftspeople of the period as they excelled in tile revetments, the monograph narrows its scope to the latter, tilework having remained the most widespread technique of architectural decoration, irrespective of dynasties. Tilework is also more enduring than other decorative practices, keeping in mind the caveat that it can even cease to be part of a built environment; it comes into being as a portable object, remains subject to disassemblage, removal and reuse throughout its life-cycle, and poses challenges for scholars who attempt to assign it to a dynasty or place of manufacture. As Aube points out, difficulties do not end here. Tiles were omitted from the creation of petrograph samples in what so far has been the most detailed physical survey of 16th-17th-century pottery, carried out by the Royal Ontario Museum in the 
1990s, and this asymmetry is gravely felt by the historian inquiring about the tilework of the same period. In the absence of such samples, the author explores other ways to contextualise the material under discussion. Her book is a complete catalogue of extant Turkmen tilework but is much more than that. It examines every known foundational inscription - both royal and non-royal -, as well as every signed ensemble, in addition to technological, stylistic, and epigraphic characteristics: and the salient features of Turkoman tile production start to emerge. Even if surviving material proved to be too scant for a comprehensive reconstruction of workshop organisation, patronage network, tileworker mobility, etc., these questions and a lot more are investigated in a carefully structured series of chapters. A comparison of textual sources about the monuments of Tabriz with extant vestiges indicates a massive loss in the main Turkmen capital. However, unexpected discoveries were made even there, the significance of which can hardly be overestimated. By introducing the almost forgotten Ḥasan Pādšāh mosque of Tabrīz vis-à-vis it is much better known Qarā Quyūnlū counterpart, the mosque of Jahān Šāh, Aube throws new light on the versatility of Tabrīzi tilemakers of the later 15th century who apparently worked without interruption during dynastic changes between the Timurids and the rival Turkmen confederations.

Certain regions, especially Central Iran and the Yazd area, as well as Eastern Anatolia, show a better state of preservation, allowing the author to demonstrate the geographic spread of the Turkmen tileworking craft. Regarding a related problem, that of the socalled "Tabrīzì masters" whose collective "signature" can be read as far as the Aegean coast, cautious suggestions are offered, similarly to the hitherto hardly ever discussed Turkmen phase of the development of cuerda seca (which Aube names "black line" after a terminology previously introduced by Yves Porter).

The volume is accompanied by nearly 300 high-resolution images and numerous line drawings, both kinds of illustration prepared mostly by the author.

\section{AUTHORS}

\section{IVÁN SZÁNTÓ}

Eötvös Loránd University, Budapest \& Austrian Academy of Sciences, Vienne 